\title{
How the efficiency of induction motor is measured?
}

\author{
S. Corino E. Romero L.F. Mantilla \\ Department of Electrical Engineering and Energy \\ E.T.S.I.I. y T. Universidad de Cantabria \\ Avda de Los Castros, 39005 Santander (Spain) \\ phone:+34 942 201381, fax:+34 942 201381, e-mail: mantillf@unican.es
}

\begin{abstract}
The efficiency is of paramount importance nowadays due to increasing electrical energy demand, increasing awareness of environmental problems as greenhouse effects and increasing fossil fuel prices.

This paper tries to show the different results between the standards for efficiency evaluation and the necessity of harmonization worldwide. Then, it is going to be explained the different standards for measurement of efficiency, and the main differences between the standards (IEEE 112, IEC 60034-2 and JEC-37).
\end{abstract}

To complete this study, it is going to be described the steps in order to estimate efficiency on the jobsite and expressed the different efficiency labels motors.

Keywords: energy efficiency, induction motor, standard. Code: 352-mantilla

\section{Introduction}

The efficiency is of paramount importance nowadays because electrical motors are major consumers of electricity in the modern industrial society; they consume approximately $69 \%$ of electricity in the industrial and approximately $36 \%$ in the tertiary sectors of the European Union [1]. Three-phase, low voltage squirrel cage induction motors are the most commonly used electric motors in industry.

Efficiency data by manufacturers are measured or calculated according to certain standards. The main differences between these standards are discussed in this paper.

There are a lot of examples of agreements, incentives and initiatives worldwide in order to promote increasing the efficiency. In Europe, there is an initiative called SEEEM (Standards for Energy Efficiency of Electric Motors Systems). SEEEM aims to stimulate and accelerate the process of harmonization in order to save energy and reduce greenhouse gas emissions.

\section{Losses and Efficiency}

\section{A. Definition of energy efficiency}

Efficiency is the ratio of mechanical energy output divided by the electrical energy input.
There are different efficiency definitions that describe the relationship between a motor's rating and efficiency test results:

- $\quad$ Tested. This refers to the efficiency measured by testing that specific motor.

- Nominal or Average Expected. Nominal values are the average values obtained after testing a sample population of the motor model.

- Nameplate. This refers to the efficiency measured by a specific standard.

- Minimum. These values are intended to represent the lowest point in the bell curve of motor efficiency distribution.

- Apparent Efficiency. This is the product of a motor's efficiency and power factor.

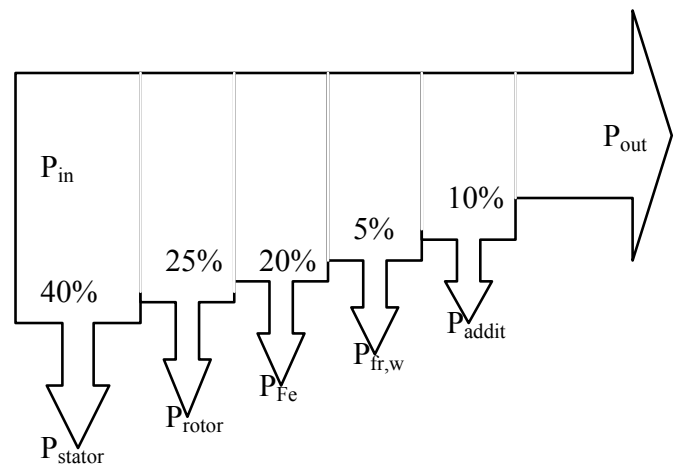

Figure 2.1 - Typical energy flow of standard motors [2].

\section{B. Motor Losses}

Energy losses are the determining factor in motor efficiency. These losses can be divided in five classes:

\begin{tabular}{|c||c||c||c||c||}
\hline \hline Name & $\begin{array}{c}\text { Percent } \\
\text { of } \\
\text { Total } \\
\text { Losses }\end{array}$ & Description & $\begin{array}{c}\text { Fixed or } \\
\text { Variable }\end{array}$ & $\begin{array}{c}\text { How to } \\
\text { reduce }\end{array}$ \\
\hline \hline & & & & $\begin{array}{c}\text { Improved } \\
\text { permeability } \\
\text { Core }\end{array}$ \\
Losses & $15-15 \%$ & $\begin{array}{c}\text { Energy } \\
\text { required to } \\
\text { magnetize } \\
\text { core. }\end{array}$ & Fixed & $\begin{array}{c}\text { lengthening } \\
\text { core, using } \\
\text { thinner }\end{array}$ \\
& & $\begin{array}{c}\text { laminations in } \\
\text { the core. }\end{array}$ \\
\hline \hline Windage & $5-15 \%$ & Losses due & Fixed & Lower friction \\
\hline
\end{tabular}




\begin{tabular}{|c|c|c|c|c|}
\hline $\begin{array}{c}\text { and } \\
\text { Friction }\end{array}$ & & $\begin{array}{l}\text { to bearing } \\
\text { friction and } \\
\text { air } \\
\text { resistance, } \\
\text { which is } \\
\text { primarily } \\
\text { caused by } \\
\text { the cooling } \\
\text { fan. }\end{array}$ & & $\begin{array}{l}\text { bearings, } \\
\text { improve fan } \\
\text { design and air } \\
\text { flow. }\end{array}$ \\
\hline $\begin{array}{l}\text { Stator } \\
\text { Losses }\end{array}$ & $25-40 \%$ & $\begin{array}{l}\text { Heating due } \\
\text { to current } \\
\text { flow } \\
\text { through the } \\
\text { resistance } \\
\text { of the stator } \\
\text { winding. }\end{array}$ & Variable & $\begin{array}{l}\text { Increasing the } \\
\text { volume of } \\
\text { copper wire in } \\
\text { the stator, } \\
\text { through } \\
\text { improved } \\
\text { stator slot } \\
\text { designs, and } \\
\text { by using } \\
\text { thinner } \\
\text { insulation. } \\
\end{array}$ \\
\hline $\begin{array}{l}\text { Rotor } \\
\text { Losses }\end{array}$ & $15-25 \%$ & $\begin{array}{l}\text { Heating due } \\
\text { to } I^{2} R \\
\text { losses in the } \\
\text { rotor } \\
\text { conductive } \\
\text { bars. }\end{array}$ & Variable & $\begin{array}{l}\text { Increasing the } \\
\text { size of rotor } \\
\text { conductive } \\
\text { bars and end } \\
\text { rings to } \\
\text { reduce } \\
\text { resistance. } \\
\end{array}$ \\
\hline $\begin{array}{l}\text { Additional } \\
\text { Load } \\
\text { Losses }\end{array}$ & $10-20 \%$ & $\begin{array}{l}\text { Leakage } \\
\text { fluxes } \\
\text { induced by } \\
\text { load } \\
\text { currents and } \\
\text { various } \\
\text { other minor } \\
\text { losses. }\end{array}$ & Variable & $\begin{array}{c}\text { Various } \\
\text { design and } \\
\text { manufacturing } \\
\text { details. }\end{array}$ \\
\hline
\end{tabular}

Table 2.1 - Classes of Motor Energy Losses [2].

The main difference between the standards emerges from the way in which the additional load losses, is treated. The IEC 34.2 standard assumes a standard value for the additional load losses at rated load of $0.5 \%$ of the input power. The new proposed IEC 61972 standard gives two possibilities for the assessment of the additional losses. The first one is a determination by means of the measured output power, as in the IEEE 112$\mathrm{B}$; the second one gives a fixed amount to every machine of the same rated power. The Japanese JEC standard 37 completely neglects the additional load losses.

$$
P_{\text {addit }}=\left(P_{\text {in }}-P_{\text {out }}\right)-\left(P_{F e}+P_{\text {stator }}+P_{\text {rotor }}+P_{f r, w}\right)
$$

\section{Motor Efficiency Testing Standards}

There are several different motor testing standards which prescribe specific procedures, such as what test equipment may be used, how long the motor is to run prior to testing, how loads are to be applied, what data are to be collected, and how various losses are to be measured.

The next table shows test standards for medium size induction motors that are used in different parts of the world.

\begin{tabular}{|c|c|c|}
\hline $\begin{array}{l}\text { United } \\
\text { States }\end{array}$ & $\begin{array}{l}\text { Institute of Electric and } \\
\text { Electronic Engineers }\end{array}$ & IEEE 112 \\
\hline $\begin{array}{l}\text { United } \\
\text { States }\end{array}$ & $\begin{array}{l}\text { American National } \\
\text { Standards Institute }\end{array}$ & $\begin{array}{l}\text { C50.20 (based on } \\
\text { IEEE 112) }\end{array}$ \\
\hline $\begin{array}{l}\text { United } \\
\text { States }\end{array}$ & $\begin{array}{lr}\text { National } & \text { Electrical } \\
\text { Manufacturers Association }\end{array}$ & $\begin{array}{l}\text { MG1-12.58.1 } \\
\text { (based on IEEE } \\
112 \text { ) }\end{array}$ \\
\hline Canada & $\begin{array}{ll}\text { Canadian } & \text { Standards } \\
\text { Association } & \\
\end{array}$ & C-390 \\
\hline International & $\begin{array}{l}\text { International } \\
\text { Electrotechnical } \\
\text { Commission } \\
\end{array}$ & IEC 34-2 \\
\hline Japan & $\begin{array}{l}\text { Japanese Electrotechnical } \\
\text { Committee }\end{array}$ & JEC-37 \\
\hline $\begin{array}{l}\text { Great } \\
\text { Britain }\end{array}$ & British Standards & BS-269 \\
\hline
\end{tabular}

Table 3.1 - Motor Testing Standards [2].

\section{A. IEEE Standard 112}

The Institute of Electric and Electronic Engineers (IEEE) Standard 112, Standard Test Procedures for Polyphase Induction Motors and Generators, is the standard used for testing induction motors in the United States.

This standard includes a total of ten test methods for efficiency. Next, we'll quote the most important:

- $\quad$ Method A: Simple Input-Output. This method is used to load the motor while the torque and speed are measured to calculate load. This is limited to small motors.

- Method B: Input-Output with loss segregation (or separation). This method uses a dynamometer. This is an instrument that maintains a constant torque resistance, allowing motor load to be calculated. This test can be used in motors from 1 to $250 \mathrm{hp}$.

- Method C: Back to back machine test with separation of losses. One machine is operated as a motor while the other becomes a generator, returning power back to the electrical grid. The efficiency is measured by dividing the total losses by two.

- $\quad$ Method F: Equivalent circuit calculation. This is usually the least accurate way to calculated motor efficiency because such a large portion of losses are not directly measured.

The IEEE 112-B standard estimates the efficiency by the direct method:

$$
\eta_{D M}=\frac{P_{o u t}}{P_{\text {in }}}
$$

The electric input power is measured using a highaccuracy wattmeter and the output power is measured using a speed sensor and a torque sensor. This is an accurate method, if the instrumentation has the desired accuracy and the test procedure is followed rigorously.

\section{B. IEC Standard 60034-2}

The IEC's test can be classified in three types: 
- Input-Output Measurement Power of one machine: This involves the measurement of mechanical input or output power.

- Input-Output Measurement Power in back-toback machines: This eliminates the measurement of mechanical input or output power.

- Measurement Real Losses of one machine: It is applied in order to calculate the total or particular losses.

It is distinguished two ways of efficiency measurement: in the direct method, the input and output power are measured directly, as the expression (2); and the indirect method measures the losses, output power is equal losses plus input power (3).

$$
\eta_{I M}=1-\frac{P_{\text {losses }}}{P_{\text {in }}}
$$

In the next paragraph, it is going to be explained the different methods that are included in this standard:

- $\quad$ Method of Tared Motor.

The machine is separated of the electrical grid and it is disconnected of its driver motor. It is achieved the full load speed thanks to the tared motor. The mechanical power that is transmitted by from the tared motor to shaft, are the power losses of the machine.

- $\quad$ Method with Power Factor zero.

The machine operates unloaded, full load speed and power factor near zero. The excitation current is regulated in order to achieve the nominal current in the primary.

Method of deceleration.

Consist in the measurement of the time applying in its deceleration. This method lets the measurement the mechanical losses, core losses and short-circuit losses.

- $\quad$ Method back-to-back.

This method can be applied when two equal machines are available. One of them operates as a motor and the other one, as a generator.

- $\quad$ Method calorimetric.

This method is being studied.

\section{Comparative cases between Standards}

The comparative cases try to prove the disagreement between different standard methods.

The following graphics are supported in a study of University of Nottingham published by CEMEP 2005.

Seven motors were tested with Standard IEEE 112E, Standard IEEE 112-B, EN 60034-2, and IEC 61972. The tests were done different sizes of motors such as $11 \mathrm{~kW}, 75 \mathrm{~kW}$ and $110 \mathrm{~kW}$.

The results can be seen in the figures 3.1, 3.2 and 3.3:

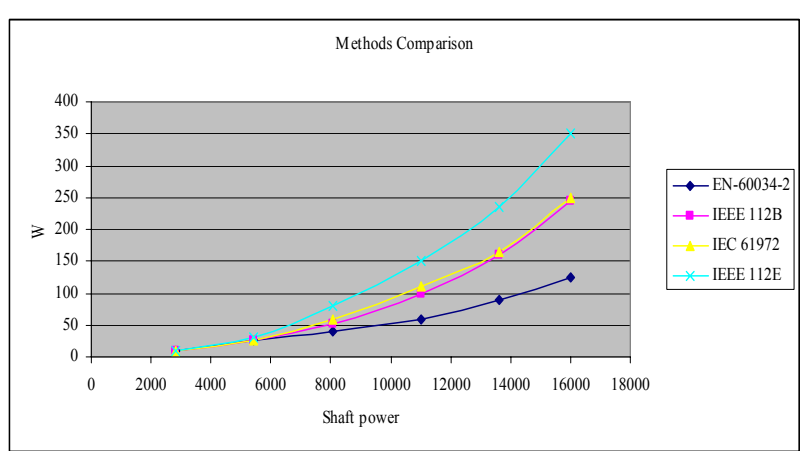

Figure 3.1 - University of Nottingham: Result of 1 of 5 motors of $11 \mathrm{~kW}[5]$.

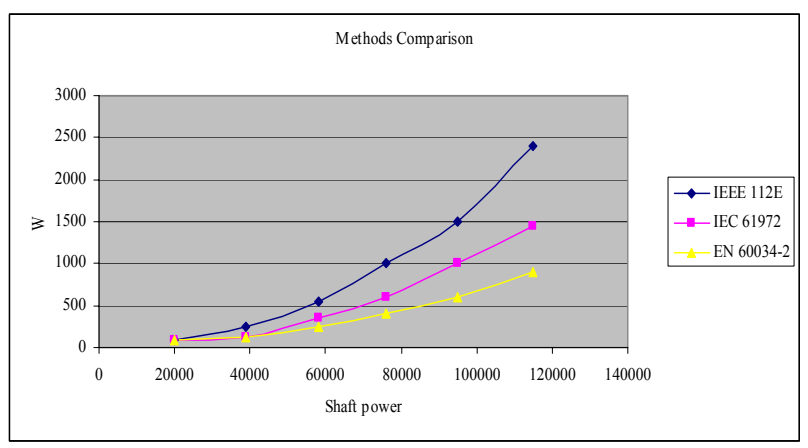

Figure 3.2 - University of Nottingham: Result of 1 of 5 motors of $75 \mathrm{~kW}$ [5].

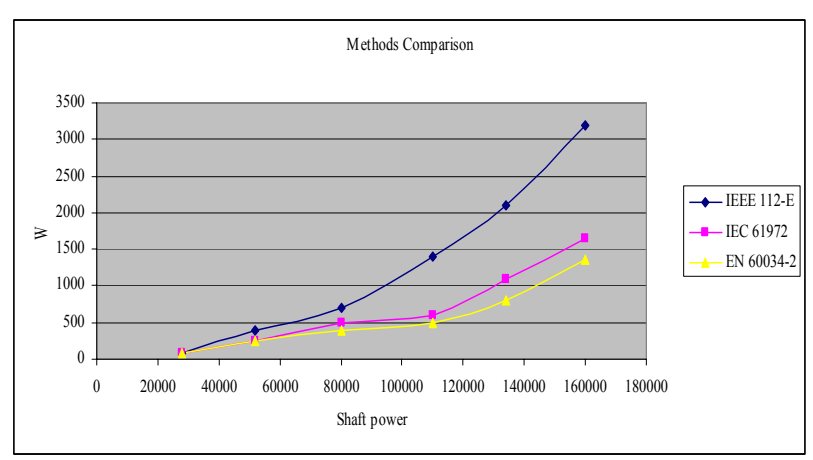

Figure 3.3 - University of Nottingham: Result of 1 of 5 motors of $110 \mathrm{~kW}[5]$.

The following table shows the results of 13 motors tested in Natural Resources Canada:

\begin{tabular}{|c||c||c||c||}
\hline Size & $\begin{array}{c}\text { Efficiency } \\
\text { with } \\
\text { indirect } \\
\text { method }\end{array}$ & $\begin{array}{c}\text { Efficiency } \\
\text { with Eh-star } \\
\text { method }\end{array}$ & $\begin{array}{c}\text { Difference } \\
\text { in } \\
\text { percentage } \\
\text { points }\end{array}$ \\
\hline \hline$(\mathrm{hp})$ & $(\%)$ & $(\%)$ & (p.p.) \\
\hline \hline 2 & 84.7 & 85.1 & 0.42 \\
\hline \hline 5 & 88.7 & 88.7 & 0.00 \\
\hline \hline 5 & 86.7 & 86.5 & -0.21 \\
\hline \hline 10 & 89.7 & 89.6 & -0.04 \\
\hline \hline 10 & 91.0 & 91.1 & 0.09 \\
\hline \hline 20 & 93.2 & 93.4 & 0.17 \\
\hline \hline 50 & 92.8 & 93.1 & 0.28 \\
\hline \hline $55 \mathrm{~kW}$ & 92.5 & 93.1 & 0.54 \\
\hline \hline 75 & 93.0 & 93.2 & 0.16 \\
\hline $90 \mathrm{~kW}$ & 93.7 & 94.4 & 0.71 \\
\hline
\end{tabular}




\begin{tabular}{||l||l||l||l||}
\hline 125 & 94.8 & 95.1 & 0.29 \\
\hline \hline 150 & 95.9 & 96.3 & 0.34 \\
\hline \hline 200 & 95.9 & 95.9 & 0.03 \\
\hline
\end{tabular}

Table 3.2 - Results of 13 test, published at the Motors Summit 2007 in Zurich [5].

The eh-star method consist an asymmetric feeding of a three-phase induction motor. The unbalanced condition is obtained by operating the motor in star connection and then switching from normal three phase to single phase operation where the disconnected phase is connected back to the supply through a resistor. Eh-star is an economical method with good accuracy where stray load losses are calculated mathematically.

\section{Estimation Efficiency on the Jobsite}

Three steps are used to estimate efficiency and load. First, use input power, line current or slip measurements to identify the load imposed on the motor. Second, obtain a motor part-load efficiency value. Finally, obtain a modified load using the power measurement at the motor terminals and the part-load efficiency value.

\section{A. Input Power Measurements}

You can then quantify the motor's part-load by comparing the measured input power under load to the power required when the motor operates at rated capacity. The relationship is shown in equation (4)

$$
\text { Load }=\frac{P_{i}}{P_{i r}} \times 100 \%
$$

With Load the output power as a \% of rated power, $\mathrm{P}_{\mathrm{i}}$, the measured three phase power in $\mathrm{kW}$; and $\mathrm{P}_{\mathrm{ir}}$, the input power al full rated load in $\mathrm{kW}$.

\section{B. Line Current Measurements}

The current load estimation method is recommended when only amperage measurements are available.

In the low load region, current measurements are no longer a useful indicator of load.

Thus, root mean square current measurements should always be corrected for voltage.

\section{The Slip Method}

The slip method is recommended when only motor operating speed measurements are available.

The motor load can be estimated with slip measurements as shown in equation (5):

$$
\text { Load }=\frac{I}{I_{r}} \times \frac{V}{V_{r}} \times 100 \%
$$

With Load, as output power as a \% of rated power, I is the RMS current (mean of 3 phases); $I_{r}$ the nameplate rated current; $\mathrm{V}$, the RMS voltage, mean line to line of 3 phases; and $\mathrm{V}_{\mathrm{r}}$, the nameplate rated voltage.

As an example [8], suppose a $460 \mathrm{~V}$ motor's "true" full-load rpm is 1760 . The slip is 40rpm. NEMA allows $\pm 20 \%$ difference between actual slip and nameplate slip when the ambient temperature is $25^{\circ} \mathrm{C}$. Thus, depending upon manufacturing and test variations, the nameplate could properly be stamped $1760 \pm 20 \%$ of $40 \mathrm{rpm}$ :

$$
\begin{aligned}
& \text { Maximum slip }=48 ; \mathrm{rpm}=1752 \\
& \text { Minimum slip }=32 ; \mathrm{rpm}=1768
\end{aligned}
$$

The accuracy of the slip method is, however, limited by multiple factors, and is generally not recommended for determining motor loads in the field.

\section{Identification of Efficiency on the Market}

A classification scheme was introduced that categorized motors into three efficiency classes depending on motor type, number of poles, and most importantly, size (see figure 5.1). There are three labels in order to classify the efficiency: Eff1, Eff2 and Eff3.

This classification is possible thanks to voluntary agreement between CEMEP (the European Committee of Manufacturers of Electrical Machines and Power Electronics) and the European Commission.

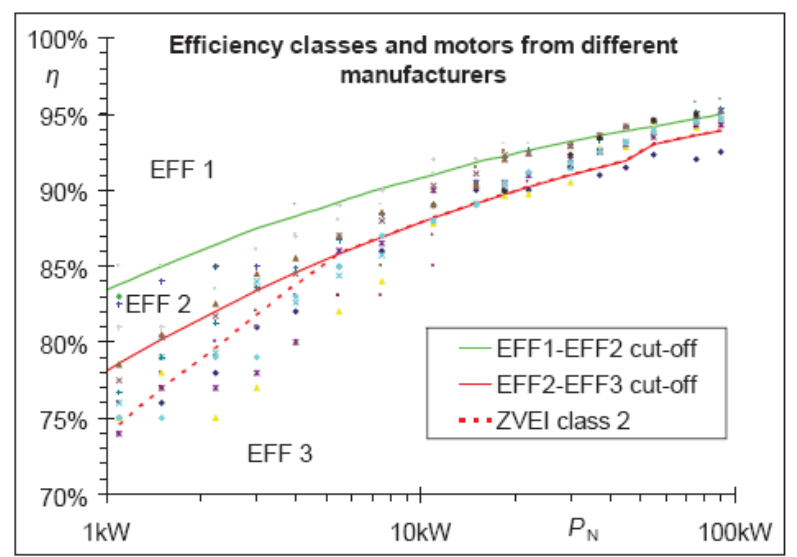

Figure 5.1 - Energy efficiency classification scheme for a range of two poles motors from different manufacturers [3].

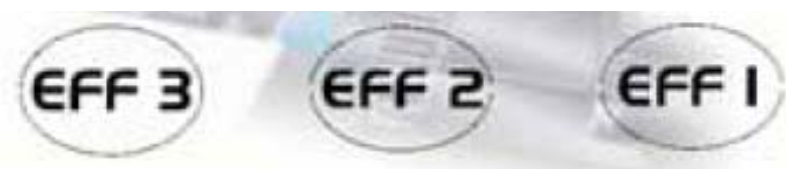

Figure 5.2 - Efficiency labels [3].

The motors included in this scheme are defined as totally enclosed fan ventilated (IP 54 or IP 55), three phase A.C. squirrel cage induction motors, $50 \mathrm{~Hz}, \mathrm{~S} 1$ duty class.

\begin{tabular}{|c||c||c|c||}
\hline $\mathbf{k W}$ & Eff3 & Eff2 & Eff1 \\
\hline \hline 1.1 & $<76.2$ & $\geq 76.2$ & $\geq 83.8$ \\
\hline \hline 1.5 & $<78.5$ & $\geq 78.5$ & $\geq 85.0$ \\
\hline \hline 2.2 & $<81.0$ & $\geq 81.0$ & $\geq 86.4$ \\
\hline \hline 3 & $<82.6$ & $\geq 82.6$ & $\geq 87.4$ \\
\hline
\end{tabular}




\begin{tabular}{||c||c||c||c||}
\hline \hline 4 & $<84.2$ & $\geq 84.2$ & $\geq 88.3$ \\
\hline \hline 5.5 & $<85.7$ & $\geq 85.7$ & $\geq 89.2$ \\
\hline \hline 7.5 & $<87.0$ & $\geq 87.0$ & $\geq 90.1$ \\
\hline \hline 11 & $<88.4$ & $\geq 88.4$ & $\geq 91.0$ \\
\hline \hline 18.5 & $<89.4$ & $\geq 89.4$ & $\geq 91.8$ \\
\hline \hline 22 & $<90.0$ & $\geq 90.0$ & $\geq 92.2$ \\
\hline \hline 30 & $<90.5$ & $\geq 90.5$ & $\geq 92.6$ \\
\hline \hline 37.4 & $\geq 91.4$ & $\geq 93.2$ \\
\hline \hline 45 & $<92.0$ & $\geq 92.0$ & $\geq 93.6$ \\
\hline \hline 55 & $<93.0$ & $\geq 92.5$ & $\geq 93.9$ \\
\hline \hline 75 & $<93.6$ & $\geq 93.0$ & $\geq 94.2$ \\
\hline \hline 90 & $<93.9$ & $\geq 93.9$ & $\geq 94.7$ \\
\hline
\end{tabular}

Table 5.1 - Efficiency of four poles motors [4].

\section{Conclusions}

The analysis presented shows that it can be obtained different results depending on the standard used. These differences have been proved thanks to graphical examples. It is necessary to eliminate the disagreements between the methods of the different standards because they make for serious consequences in order to certificate and to declare efficiency values.

This fact can be got through International Harmonization Initiative promoting by SEEEM. This process of harmonization deals the energy saving and the reduction greenhouse emissions.

To sum up, this study has tried to shed light of knowledge of different standards for efficiency measurement and to emphasize the necessity of harmonization worldwide.

\section{References}

[1] H. Falkner, "Promoting High Efficiency Motors in Europe. The role of the copper Industry", ETSU. European Copper Institute, pp. 13, November 2000.

[2] T. Litman, "Efficient Electric Motor Systems Handbook", The Fairmont Press, INC., Oklahoma (1995), pp. 21-37.

[3] S. Fassbinder, "Saving energy with high-efficiency motors", Leonardo Energy, pp. 6-7, September 2007. http://www.leonardo-energy.org

[4] EURODEEM New Features Added, December 2007. http://sunbird.jrc.it/energyefficiency/eurodeem/index.htm

[5] C.U.Brunner, "International Standards for Electric Motors", Standards for Energy Efficiency of Electric Motor Systems (SEEEM), pp. 6-10, November 2007. http://www.seeem.org

[6] A. T. de Almeida, F. J. T. E. Ferreira, et al, "Comparative Analysis of IEEE 112-B and IEC 34-2 Efficiency Testing Standards Using Stray Load Losses in Low-Voltage Three-
Phase, Cage Induction Motors", Vol. 38, No. 2, pp.609-613, March/April 2002.

[7] P. Van Roy and R. Belmans, "Assessment of Efficiency of Low Voltage Three Phase Motors”, pp. 95-96, Berlin 2003.

[8] "Understanding Energy Efficiency Motors", Electrical Apparatus Service Association (EASA), pp. 15-20. http://www.easa.com/

[9] G. A. McCoy and J. G. Douglas, "Energy Management for Motor-Driven Systems", The U.S. Department of Energy Office of Industrial Technologies, Washington, March 2000, pp 5.15.8 . 